\title{
Introduction
}

\section{Symposium: What is Real about Law and Technology?}

\author{
Kieran Tranter \\ Queensland University of Technology, Australia \\ Edwin Bikundo \\ Griffith University, Australia \\ Charles Lawson ${ }^{1}$ \\ Griffith University, Australia
}

This introduction orientates the seven articles that comprise the 'What is Real about Law and Technology Symposium'. This symposium was inspired by Bruno Latour's and Giorgio Agamben's 2018 books that seemingly respond to the election of Donald Trump, by reconceptualising the relation between the real and representation. It is suggested that the irresolvability of Being (that humans can only experience the real through culture) should ground a more nuanced location between constructivism and empiricism. How to think about and explore this, in relation to law and technology, is precisely the challenge to which the articles in this symposium respond.

\section{Really...}

This introduction is being written after two falls. First, it is being written in the days after Democrat challenger Joe Biden claimed victory in the 2020 United States presidential election. This announcement on 8 November, notwithstanding contested legalities and spirited challenges, possibly marked the fall of the 45th President of the United States, Donald Trump. It is also being drafted after the fall of one of us while bushwalking causing a ruptured quadriceps tendon, an elevated leg and reattachment surgery in the following days.

The fall of Trump was marked by unreality. There have been the characteristic tweet bursts and rambling press conferences claiming — what seems at this time-unsubstantiated allegations of voter fraud. Consistent with his 4-year term, Trump's reaction to his electoral defeat was to shoot off denial, CAPS LOCK aggression and claims of falseness and conspiracies. There is a witnessing of the real that the people have spoken through, by credible accounts, valid and verifiable electoral processes being brazenly contested within the semiosphere. This time, perhaps, 'the reality-based community', so denigrated by an aide to former president George W Bush, will have its revenge served cold. ${ }^{2}$

\footnotetext{
${ }^{1}$ Kieran Tranter: Chair and Chief Editor of Law, Technology and Humans, Queensland University of Technology. Contact k.tranter@qut.edu.au.

Edwin Bikundo: Senior Lecturer, Law Futures Centre, Griffith Law School, Griffith University.

Charles Lawson: Professor, Law Futures Centre and Environmental Futures Research Institute, Griffith Law School, Griffith University.

${ }^{2}$ Suskind, "Faith, Certainty and the Presidency."
} 
The other fall involved another real. It was the real of physics involving gravity, mass and the elasticity of soft tissue causing injury. It was the everyday reality that a body on the earth can be subject to trauma external to any system of signs or contested fields of knowledge. How culture then interprets and processes a wounded body, whether it is afforded sympathy and care, or derision and abandonment, is entirely within the realms of the symbolic. But, at the moment of injury, nothing suggests a primal, ulterior reality more than blood and broken limbs. The condemned might contest the legitimacy of their executioners, but their bodies cannot interpret or deny the firing squad's bullets—-the laws of physics trump the law's fixity.

In these falls, there are two reals. The first is the real of culture —of what is known and accepted as right and true. This is more robust than it might appear. It is through this 'cultural real' that the collective endeavours of humanity-from language to the economy - endure, notwithstanding subjectivity, interpretation and the lonely projection of the monad individual denied true community due to the vagaries of expression. The second is the myth of nature - of a real that is external and beyond the human. A sovereign to which human doing and possibility must account. This is the planet in contemporary climate change discourse, or human nature in liberalist thinking, or the indefatigable operation of the mode of production in dialectical materialism, or sin and eternal damnation for the fire and brimstone preacher. There is real, and there will be a reckoning.

The jumbling and interceding of these two reals has been the engine for the 'Science Wars' over the past 30 years. Modern science, as Martin Heidegger clearly delineated, occupies a place wherein all that is has become ordered and measured. ${ }^{3}$ Modern science is human doing that denies its humanity; it occupies a revealing of the world as 'objective facts' discoverable by a 'process' and able to be synthesised into useful 'laws' to further human doing. ${ }^{4}$ Science, particularly institutional science of the 20th century, was an activity that denied that it was cultural. Instead, it was the privileged way to the real; its empiricism established an empire of objects to be known and used by humans. The Science Wars represented the return of what was repressed by the bold claim of modern science: that culture, language, politics, race, gender and - heaven forbid-funding all influenced the production of scientific knowledge. Science was a discourse or machine built to present and stabilise a representation of the real, rather than the one objective, true path to the real.

Such claims resonated within a Western culture that, in the 1980s and 1990s, was - to quote the much repeated phrase at the time - experiencing 'incredulity towards metanarratives' ${ }^{5}$ At the same time, the last child of the War- the digital computer ${ }^{6}$ had entered its adolescence, and with it emerged cyberpunk dreams of simulacra and silicone-supported realities. ${ }^{7}$ The real was in retreat against a revitalised culture and a gamer space of pure possibilities. This was a period when geopolitical realities changed through people power, and the emerging 'World Wide Web' promised freedom beyond the constraints of geography, nations and capitalism. ${ }^{8}$ Human potential, unencumbered by the real of place or history, seemed, for want of a better word, 'real' at the millennium.

However, by 2016, this reality of no reality had seemingly gone. The digital quickly established itself as a dangerous place of predators, trolls and platform capitalism. Instead of freedom, there was danger, exploitation and data serfdom. The liberatory calls for science (and history) to be open to their own subjectivity was simultaneously denied and coopted by sites of privilege to bolster the status quo. The West, now considered the Global North, experienced a series of civil wars: the aforementioned Science Wars, the 'Culture Wars' and the 'Climate Wars'. What was real and what was true became contested and contestable. It is in this location that Trump became president-embodying, exploiting and expanding on this essential epistemological crisis. The real had become 'fake news'.

In 2018, both Bruno Latour and Giorgio Agamben published books addressing the epistemological crisis personified by Trump. ${ }^{9}$ Both could be read by cynical observers as attempts to reorientate their intellectual legacies in the age of Trump. For Latour, Down to Earth might be read as a challenge to suggestions that his studies of science and scientists contributed to a constructivism that fuelled climate science scepticism. For Agamben, What is Real could be seen as an attempt to shift his account of the pathologies of sovereignty and the modern state in the ban and exception (that does not distinguish between liberal, communist and fascist forms) to a more governmentality-like emphasis on statistics and a quantum physics-inspired

\footnotetext{
${ }^{3}$ Heidegger, "Age of World Picture."

${ }^{4}$ Heidegger, "Age of World Picture," 120-4.

${ }^{5}$ Lyotard, Postmodern Condition, xxiv.

${ }^{6}$ Kittler, Gramophone, Film, Typewriter.

${ }^{7}$ Baudrillard, Simulacra and Simulation.

${ }^{8}$ Lessig, Code and Other Laws of Cyberspace.

${ }^{9}$ Latour, Down to Earth; Agamben, What Is Real?
} 
managing of uncertainty. What was important in both of these was a recognition of the need for a more nuanced engagement with the real, a need to possibly bring back, to some form of balance, the irresolvable tension of being in which humans can only make sense of the experience of the world through culture - the being of Being, as cryptically suggested by Heidegger. There is the lesson that this does not validate a wilful and irresponsible embrace of pure constructiveness nor a return to dogmatic empiricism; rather, an acknowledgement of a quantum-like state of both, simultaneously. After all, as Heidegger noted in 'The Question Concerning Technology':

\begin{abstract}
Modern physics is not experimental physics because it applies apparatus to the questioning of nature. Rather the reverse is true. Because physics, indeed already as pure theory, sets nature up to exhibit itself as a coherence of forces calculable in advance, it therefore orders its experiments precisely for the purpose of asking whether and how nature reports itself when set up in this way. ${ }^{10}$
\end{abstract}

This symposium emerged from perceiving this common agenda in Latour and Agamben and through wondering how these concerns might play out for law and technology. In what follows, there are two levels of engagement.

First, contributions by David S Caudill, Charles Lawson and Edwin Bikundo engage directly with Latour and Agamben. Caudill revisits and reminds of the legacy of the Science Wars for the Trump White House. Lawson tracks the estranged figure of the real through Latour. Bikundo examines how, for Agamben, the 'experiment' - that essential event of modern science-is an exposé of the intersection of power and knowledge, where the human is both observer and observed.

Second, contributions engage with the real in relation to law and technology. Elizabeth Englezos uses Charles Sanders Peirce's semiotics to focus on digital translation and digital determinations of material reality. Heather J Van Meter revisits the utility of the 'Data, Information, Knowledge and Wisdom Pyramid' in concerns with governance in and through the digital. Chris Dent directly engages with the Foucauldian legacy in making sense of the emerging algorithmic techno-totality. Finally, Ernesto A Hernández-López comes 'down to earth' through looking at how legal challenges to GMO corn in Mexico can be seen as reflecting a Latourian call for real politics of place and purpose in challenge to globalisation and modernism.

Drafts of these papers were presented at an in-person workshop in December 2019 at the Queensland University of Technology Gardens Point campus in Brisbane, Australia. At the time an unremarkable coming together of scholars, now seems somewhat surreal given the realities of the COVID-19 pandemic. We would particularly like to thank Belinda Carpenter for the support for the workshop and the astoundingly outstanding Tracy Creagh for her amazing support for the symposium and the Journal generally. We would also like to thank Lyria Bennett-Moses and Dan Hunter for their roles as discussants during the workshop. Finally, our deepest thanks to the contributors for going on this journey with us and entrusting to us their thoughts and work. We thank them for keeping it real.

\title{
Bibliography
}

Agamben, Giorgio. What Is Real? Translated by Lorenzo Chiesa. Stanford: Stanford University Press, 2018.

Baudrillard, Jean. Simulacra and Simulation. Translated by Shelia Faria Glaser. Michigan: University of Michigan Press, 1994.

Heidegger, Martin. "The Age of World Picture." In The Question Concerning Technology and Other Essays, 115-54. Translated by William Lovitt. New York: Harper \& Row, 1977.

Heidegger, Martin. “The Question Concerning Technology.” In The Question Concerning Technology and Other Essays, 335. Translated by William Lovitt. New York: Harper \& Row, 1977.

Kittler, Friedrich A. Gramophone, Film, Typewriter. Translated by Geoffrey Winthrop-Young and Muchael Wutz. Stanford: Stanford University Press, 1999.

Latour, Bruno. Down to Earth: Politics in the New Climatic Regime. Translated by Cathy Porter. London: Polity, 2018.

Lessig, Lawrence. Code and Other Laws of Cyberspace. New York: Basic Books, 1999.

Lyotard, Jean-François. The Postmodern Condition: A Report on Knowledge. Translated by Geoff Bennington and Brian Massumi. Minneapolis: University of Minnesota Press, 1984.

Suskind, Ron. "Faith, Certainty and the Presidency of George W. Bush," New York Times, October 17, 2004. https://www.nytimes.com/2004/10/17/magazine/faith-certainty-and-the-presidency-of-george-w-bush.html.

\footnotetext{
${ }^{10}$ Heidegger, "Question Concerning Technology," 21.
} 